\title{
Analisis Faktor Penghambat Implementasi Pembelajaran Daring Siswa SD Inpres 68 Kota Sorong
}

\author{
Nilam Pangestika ${ }^{1}$, Muhammad Faizin ${ }^{2} \&$ Mursalim $^{3}$
}

\author{
Prodi PGSD, Universitas Pendidikan Muhammadiyah Sorong, Indonesia \\ ${ }^{\otimes}$ E-mail: nilampangestika20@gmail.com
}

\begin{abstract}
Abstrak
Penelitian ini bertujuan untuk mengetahui faktor penghambat implementasi pembelajaran daring dan mendeskripsikan cara implementasi pembelajaran daring siswa SD Inpres 68 Kota Sorong. Penelitian ini menggunakan pendekatan descriptive qualitative. Teknik yang digunakan adalah teknik wawancara, dan dokumentasi. Subjek penelitian ini adalah guru dan siswa. Analisis data redukasi data, penyajian data, dan penarikan kesimpulan. Pengecekan keabsahan data menggunakan triangulasi sumber data dan triangulasi metode. Hasil penelitian ini menunjukkan bahwa 1) faktor penghambat implemenatsi pembelajaran daring ada 5 yaitu: a) tidak bisa akses aplikasi belajar daring dimana Guru dan siswa masih belum paham tentang bagaimana cara menggunakan aplikasi belajar daring, b) keterbatasan ekonomi sehingga tidak semua siswa memiliki hp c) jaringan internet kurang baik dimana masih banyak siswa yang menggunakan jaringan seluler sehingga dalam membuka materi yang telah dibagikan oleh guru menjadi terhambat, d) biaya tinggi karena banyak siswa yang mengeluh mengenai biaya kuota walaupun dari pemerintah sudah ada namun dianggap tidak cukup, dan e) kurangnya pendampingan orang tua yang cenderung memiliki kesibukan pekerjaan dan 2) Implementasi pembelajaran daring menggunakan aplikasi whatsApp guru menyampaikan materi pembelajaran melalui WAG (WhatsApp Group). Kesimpulan dari penelitian ini adalah terdapat beberapa faktor penghambat dalam pembelajaran daring dan pembelajaran daring menggunakan bantuan aplikasi whatsapp.
\end{abstract}

Kata Kunci: Pembelajaran Daring; Whatsapp Group; Siswa SD.

\begin{abstract}
This study aims to determine the inhibiting factors for the implementation of online learning and describe how to implement online learning for students at SD Inpres 68 Sorong City. This study uses a descriptive qualitative approach. The technique used is interview technique, and documentation. The subjects of this research are teachers and students. Data analysis data reduction, data presentation, and drawing conclusions. Checking the validity of the data using triangulation of data sources and triangulation of methods. The results of this study indicate that 1) there are 5 inhibiting factors for the implementation of online learning, namely: a) not being able to access online learning applications where teachers and students still do not understand how to use online learning applications, $b$ ) economic limitations so that not all students have cellphones. ) the internet network is not good where there are still many students who use the cellular network so that in opening the material that has been distributed by the teacher it becomes hampered, d) the cost is high because many students complain about the quota fee even though the government already exists but it is considered insufficient, and e) lack of assistance from parents who tend to have busy work and 2) Implementation of online learning using the WhatsApp application, the teacher delivers learning materials through WAG (WhatsApp Group). The conclusion of this study is that there are several inhibiting factors in online learning and online learning using the help of the whatsapp application
\end{abstract}

Keywords: Online Learning; Whatsapp Group; Elementary School Students. 


\section{PENDAHULUAN}

Pandemi Covid-19 yang terjadi di beberapa negara di dunia termasuk Indonesia belum juga berakhir. Upaya pemerintah demi mencengah penyebaran virus ini dengan cara pembatasan interaksi (Social distancing) untuk sekolah, perkantoran dan fasilitas umum lainnya. Dampaknya, pembelajaran dilakukan secara daring dengan jarak jauh antara guru dengan siswa. Menteri Nadiem menerbitkan Surat Edaran Nomor 3 Tahun 2020 pada Satuan Pendidikan dan Nomor 36962/MPK.A/HK/2020 tentang

Pelaksanaan Pendidikan dalam Masa Darurat Covid-19 maka kegaiatan belajar dilakukan secara daring dalam rangka pencegahan penyebaran Covid-19.

Social Distancing dilaksanakan diseluruh Provinsi dan Kota Indonesia, salah satunya di Kota Sorong. Penerapannya membuat seluruh aktifitas masyarakat dilakukan di rumah, salah satunya adalah kegiatan belajar mengajar. Kegiatan belajar mengajar yang seharusnya dilakukan di sekolah harus dilaksanakan di rumah untuk sementara waktu.

SD di Kota Sorong menerapkan pembelajaran daring dan pembelajaran jarak jauh (PJJ). Ada yang menerapkan pembelajaran daring menggunakan media whatsapp group (WAG) dan Google Classroom (GCR). Dengan menggunakan WAG, guru mengirim materi, memberi tugas, dan melakukan interaksi/diskusi dengan siswa secara daring. Disisi lain, kemampuan guru dalam menggunakan aplikasi/media pembelajaran daring sangat dibutuhkan dan yang paling utama adalah konektifitas yang baik untuk jaringan internet. Bukan tidak mungkin akan muncul masalah-masalah terkait pembelajaran daring apabila dua indikator tersebut tidak terpenuhi. Bahkan, dibeberapa tempat mungkin saja ada indikator lain yang menjadi faktor yang mempengaruhi pembelajaran yang dilakukan secara daring.

Berdasarkan uraian diatas, perlu dilakukan analisis terkait faktor-faktor yang mempengaruhi pembelajaran daring yang dilakukan di SD di kota sorong. Dalam hal ini, sekolah yang menjadi subjek penelitian adalah guru dan siswa yang berada di SD Inpres 68 Kota Sorong. Yang menjadi fokus penelitian adalah untuk mendeskripsikan faktor-faktor penghambat implementasi pembelajaran daring dan untuk mendeskripsikan implementasi pembelajaran daring di SD Inpres 68 Kota Sorong.

Daring merupakan nomenklatur dari dalam jaringan, pembelajaran yang dilakukan dengan memanfaatkan jaringan internet. Pembelajaran daring dapat dilakukan dimanapun, kapanpun, dan memudahkan para siswa untuk belajar. Bilfaqih \& Qomarudin (2015:1) menyatakan bahwa pembelajaran daring merupakan program penyelenggaraan kelas pembelajaran dalam jaringan untuk menjangkau kelompok target yang masif dan luas.

Menurut Romli (2012:34) dalam Cintiasih (2020:21) Pengertian media daring secara umum adalah segala jenis atau format media yang hanya bisa diakses melalui internet berisikan teks, foto, video dan suara, sebagai sarana komunikasi secara daring, sedangkan pengertian khusus media daring dimaknai sebagai sebuah media dalam konteks komunikasi massa.

Menurut Laelasari, dkk (2016:9) menyatakan bahwa pembelajaran daring memiliki karakteristik; a) pembelajaran dilakukan dengan memanfaatkan jasa teknologi elektronik, dimana pelaku pembelajaran berkomunikasi tanpa dibatasi aturan atau protokol tertentu; b) pembelajaran dengan memanfaatkan 
keunggulan komputer (digital media dan computer network); c) pembelajaran dilakukan dengan menggunakan bahan ajar yang bersifat mandiri dan bebas, yang disimpan di komputer sehingga dapat diakses pendidik dan peserta didik kapan dan dimana saja; d) pembelajaran dengan memanfaatkan kurikulum, jadwal pembelajaran, hasil kemajuan belajar dan administrasi pendidikan yang dapat dilihat setiap saat di komputer.

Isman (2017:587) menambahkan, pembelajaran daring memiliki karakteristik; a) pembelajaran akan berkolaborasi dengan pembelajaran lain dalam membangun pengetahuannya dan memecahkan masalah secara bersama-sama (social constructivism); b) membentuk suatu komunitas pembelajaran (community of learners) yang inklusif; c) memanfaatkan media laman (website) yang bisa diakses melalui internet, pembelajaran berbasis komputer, kelas virtual, dan atau kelas digital; dan d) interaktivitas, kemandirian, aksesibilitas, dan pengayaan.

Faktor yang mempengaruhi pembelajaran daring telah dipaparkan sebelumnya oleh Syafira (2020) dan Girsang (2020). Mereka merumuskan faktor-faktor yang menjadi pengaruh terhadap pembelajaran daring a) yaitu akses aplikasi belajar online dan koneksi internet, b) kesenjangan ekonomi siswa dan guru, contohnya adalah tidak semua memiliki HP dan smartphone, d) biaya tinggi, dan e) pendampingan orang tua atau wali.

\section{METODE PENELITIAN}

Penelitian ini menggunakan jenis penelitian kualitatif. Dalam penelitian ini menggunakan pendekatan Fenomologi dengan mengkhususkan pada fenomena dan realitas yang tampak untuk mengkaji penjelasan di dalamnya. Penelitian ini dilaksanakan di SD Inpres 68 Kota Sorong kelas VI A dijalan Sungai Kamundan Kota Sorong. Subjek penelitian ini adalah guru kelas VI A di SD Inpres 68 Kota Sorong yang berjumlah 2 orang guru dan siswa kelas VI A di SD Inpres 68 Kota Sorong yang berjumlah 5 orang.

Data primer dalam penelitian ini diperoleh dengan cara wawancara dengan guru kelas terkait faktor penghambat pembelajaran daring yang penulis akan bahas dan di laksanakan di SD Inpres 68 Kota Sorong. Data sekunder di dapat dari penulis dengan melihat buku yang terkait dengan proses pembelajaran daring, jurnal dari penelitian terdahulu dan dokumentasi dilaksanakan di SD Inpres 68 Kota Sorong.

Teknik analisis data yang digunakan adalah pengumpulan data, reduksi data, penyajian data dan penarikan kesimpulan atau verifikasi.

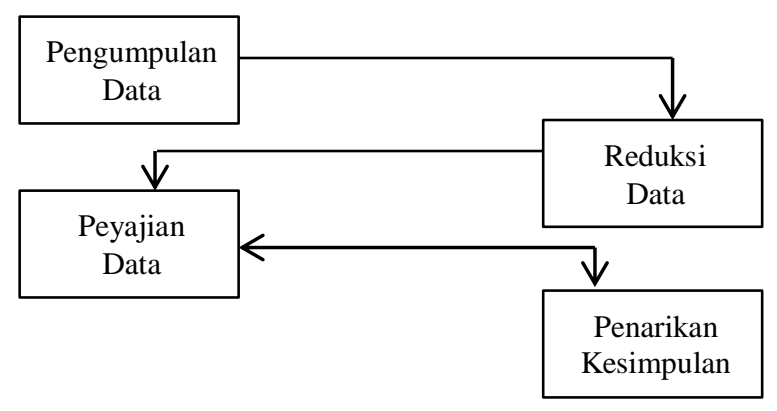

Gambar 1. Skema Model Analisis Interaktif

Pada tahap reduksi data, dilakukan pemilihan tentang relevan tidaknya antara data dengan tujuan penelitian. Data yang diperoleh dari penelitian yang beragam dengan memadukan beberapa teknik. Informasi dari lapangan sebagai bahan mentah yang kemudian diringkas, disusun lebih sistematis, serta ditonjolkan pokokpokok yang penting sehingga lebih mudah dikendalikan. Setelah tahap mereduksi data selesai dilakukan,

Pada tahap penyajian data, klasifikasi 
dan penyajian data dilakukan sesuai dengan pokok permasalahan yang diawali dengan pengkodean pada setiap sub pokok permasalahan. Untuk memudahkan memperoleh kesimpulan dari lapangan, maka penyajian data bisa dilakukan dalam bentuk uraian singkat, bagan, serta hubungan antar teori.

Tahap terakhir yaitu penarikan kesimpulan dan verifkasi. Dimana peneliti mencari makna dalam data yang dikumpulkan, kemudian disimpulkan untuk menjawab rumusan masalah dalam penelitian.

\section{HASIL DAN PEMBAHASAN}

Faktor penghambat dalam melakukan pembelajaran daring terhadap siswa dan guru terjadi karena beberapa faktor yaitu: tidak bisa akses aplikasi belajar online, keterbatasan ekonomi dan siswa tidak punya Handphone (HP), jaringan internet, biaya, kurang bimbingan guru, kurang dampingan orang tua. Adapun informan yang berjumlah 2 orang guru dan 20 siswa.

\section{Tidak Bisa Akses Aplikasi Belajar Online}

Berdasarkan hasil wawancara dengan AN selaku wali kelas VI A mengatakan bahwa:

"Menggunakan aplikasi WhatsApp, dengan menggunakan aplikasi WhatsApp sangat efektif dalam melakukan proses pembelajaran daring serta membantu dalam berkomunikasi dengan para siswa. Setiap pagi siswa absen di grup kelas. Setelah itu guru memberikan rangkuman materi serta video pembelajaran. Adapun tugas yang dikumpulkan secara lisan dan dikumpulkan secara via WhatsApp". (wawancara tanggal 10 Agustus 2021).

Guru hanya menggunakan aplikasi WhatsApp dalam melakukan pembelajaran daring dan tidak menggunakan aplikasi yang lainnya. Hal tersebut juga diperkuat dari hasil wawancara dari ke 20 siswa kompak mengatakan bahwa:

"Mengetahui informasi dari grup kelas mengunakan aplikasi WhatsApp". (wawancara tanggal 12-14 Agustus 2021).

Begitupun siswa, mereka masih bingung saat menggunakan aplikasi online. Hal ini diperkuat dari hasil wawancara dengan AN mengatakan bahwa:

"Masih banyak siswa yang belum paham maka dari itu perlu pendampingan dari orang tua karena yang mendampingi anak dirumah bukan guru melainkan orang tua". (wawancara tanggal 10 Agutus 2021).

Berdasarkan hasil wawancara yang telah dilakukan, maka dapat diketahui bahwa guru dan siswa belum bisa menggunakan aplikasi belajar dengan baik. Guru hanya menggunakan aplikasi WhatsApp dalam pembelajaran daring. Siswa masih kesulitan dalam mengakses aplikasi belajar online.

\section{Keterbatasan Ekonomi dan Siswa Tidak Punya HP}

Hp dan Laptop merupakan salah satu sarana yang penting untuk melakukan pembelajaran daring. Dalam hal ini, tentunya pihak sekolah membantu guru sebagai penunjang pembelajaran daring. Hal tersebut diperkuat dengan hasil wawancara dengan FS selaku kepala sekolah, hal ini berdasarkan hasil wawancara FS mengatakan bahwa:

"Pihak sekolah hanya dapat memfasilitasi guru dengan memberikan Laptop pinjam. Kalau HP guru memakai pribadi termasuk saya juga menggunakan HP Pribadi." (wawancara tanggal 10 Agustus 2021).

Dari pernyatan diatas guru mendapat laptop pinjaman dari pihak sekolah. HP juga merupakan penunjang bagi siswa dalam proses pembelajaran daring. Banyak siswa yang masih menggunakan HP orang tua saat proses belajar. Hal ini disampaikan dalam wawancara dengan AN selaku wali kelas VI 
A mengatakan bahwa:

"Sebagian siswa sudah memiliki HP dan sebagian masih menggunakan HP orang tua. Tetapi masih banyak siswa yang menggunakan HP orang tua sehingga saat mengumpulkan tugas mereka jadi terlambat mengerjakan". (wawancara tanggal 10 Agustus 2021).

Berdasarkan hasil wawancara yang telah dilakukan, maka dapat diketahui bahwa pihak sekolah memfasilitasi guru dengan meminjamkan Laptop dan masih banyak siswa yang belum memiliki HP pribadi. Sehingga saat guru memberikan materi siswa terlambat membuka dan terlambat saat mengerjakan tugas.

\section{Jaringan Internet}

Pembelajaran

daring tentu

membutuhkan jaringan internet yang memadai. Tetapi letak geografis yang jauh dari jangkauan internet dan faktor cuaca dapat membuat akses internet tidak lancar. Baik guru dan siswa tidak semuanya berlangganan wifi dirumahnya. Di wilayah guru jaringan internet sudah memadai hal ini berdasarkan hasil wawancara dengan AN selaku wali kelas VI A mengatakan bahwa:

"Memadai karena menggunakan wifi namun terkadang terjadi gangguan karena saat ada pemadaman listrik. Ada satu siswa yang tinggal didaerah yang sulit dijangkau yaitu di Makbon, disana sinyal internet hilang-hilang sehingga siswa itu kadang terlambat saat melakukan presensi dan menerima materi." (wawancara tanggal 10 Agustus 2021).

Berdasarkan hasil wawancara yang telah dilakukan, maka dapat diketahui bahwa masih banyak siswa yang menggunakan jaringan seluler untuk memanfaatkan jaringan internet. Faktor cuaca menjadi salah satu penghambat dalam hal jaringan internet. karena banyak siswa yang menggunakan jaringan seluler sebagai sarana untuk menjangkau jaringan internet.

\section{Biaya}

Pembelajaran daring tentunya memerlukan biaya untuk membeli pake atau kuota data. Guru dan siswa sangat membutuhkan paket data untuk menunjang pembelajaran daring. Banyak siswa yang mengeluh tentang biaya kuota internet, hal tersebut berdasarkan hasil wawancara AN selaku wali kelas VI A mengatakan bahwa:

"Walaupun pemerintah memberikan paket data/kuota namun dirasa tidak cukup untuk digunakan dalam 1 bulan karena siswa banyak mendowlnload video serta materi pembelajaran. Banyak siswa yang mengeluh apalagi di masa pandemi seperti ini ada orang tua yang tidak punya pekerjaan tetap sehingga kesulitan juga dalam memperoleh uang. Kalau bagi guru ada walaupun tidak rutin, dan untuk siswa, dari pihak sekolah sudah meminta nomor masing-masing anak untuk didaftarkan agar mereka mendapatkan pulsa data/kuota 1 bulan sekali dari pemerintah". (wawancara tanggal 10 Agustus 2021).

Hasil wawancara dengan FS selaku kepala sekolah, hal ini berdasarkan hasil wawancara FS mengatakan bahwa:

"Jelas banyak, saya rasa pemberian paket data jika diberikan hanya 1 bulan itu tidak cukup karena siswa mendownload berbagai macam video pembelajaran. Banyak guru yang menyampaikan kepada saya banyak siswa yang mengeluh apalagi di masa pandemi seperti ini ada orang tua yang tidak punya pekerjaan tetap sehingga kesulitan juga dalam memperoleh uang." (wawancara tanggal 10 Agustus 2021).

Hal serupa dikatan juga oleh kelima siswa yang diwawancarai, dari ke 20 siswa mengatakan bahwa ada pulsa data dari pemerintah.

Berdasarkan hasil wawancara yang telah dilakukan, maka dapat diketahui bahwa paket data yang diberikan pemerintah untuk guru dan siswa dirasa tidak cukup untuk pemakaian satu bulan. Sehingga para siswa dan guru harus membeli paket data dengan 
anggaran yang besar disetiap bulannya.

\section{Kurang Bimbingan Guru}

Kurang bimbingan dari guru merupakan salah satu penghambat dalam pembelajaran daring. Hal ini terjadi karena kurangnya komunikasi yang terjadi antara guru dan siswa. Minimnya komunikasi guru dan siswa tentunya akan membuat siswa sulit dalam memahami materi maupun dalam mengerjakan tugas. Namun yang peneliti lakukan tidak ada kukurangan dalam hal bimbingan guru. Hal ini berdasarkan hasil wawancara dengan AN selaku wali kelas VI A mengatakan bahwa :

"Guru bukan hanya mendapat pelatihan tentang bagaimana cara menggunakan aplikasi pembelajaran daring, tetapi ada beberapa masukan dari kepala sekolah mengenai cara berkomunikasi diantara siswa dan guru saat masa pandemi seperti ini. Jadi kami para guru tidak kesulitan dalam berkomunikasi dengan siswa walaupun ada beberapa siswa yang terkadang sulit dihubungi tetapi jika ada siswa yang seperti itu kita langsung menghubungi wali siswa sehingga tidak terjadi miskomunikasi". (wawancara tanggal 10 Agustus 2021).

Hal senada yang dipaparkan dari hasil wawancara dengan FS selaku kepala sekolah, hal ini berdasarkan hasil wawancara FS mengatakan bahwa:

"Saya rasa tidak ada hambatan mengenai komunikasi antara siswa dan guru. Saya memberikan sedikit masukan mengenai cara berkomunikasi diantara siswa dan guru saat masa pandemi seperti ini. Jadi saya tidak kesulitan dalam berkomunikasi dengan siswa walaupun ada beberapa siswa yang terkadang sulit dihubungi tetapi jika ada siswa yang seperti itu saya langsung menghubungi wali murid sehingga tidak terjadi miskomunikasi." (wawancara tanggal 10 Agustus 2021).

Dari paparan diatas komunikasi antara guru dan siswa tidak menjadi kendala dalam proses pembelajaran daring. Hal serupa dikatakan oleh ke 20 siswa saat dilakukan wawancara, ke 20 siswa tersebut mengatakan bahwa komunikasi antar guru dan siswa berjalan dengan lancar dan pada akhir proses pembelajaran ada sesi Tanya jawab antara guru dan siswa mengenai materi yang baru dipelajari.

Berdasarkan hasil wawancara yang telah dilakukan, komunikasi antara guru dan siswa berjalan dengan baik karena ada arahan dan masukan dari kepala sekolah mengenai cara berkomunikasi dengan siswa. Diawal proses pembelajaran, guru selalu memberi arahan tentang pengguanan aplikasi yang dipakai dan diakhir proses pembelajran selalu ada sesi Tanya jawab yang dilakukan siswa.

\section{Kurang Dampingan Orang Tua}

Dampingan orang tua saat melakukan pembelajaran daring sangatlah penting. Banyak siswa yang terlambat melakukan presensi online, terlambat saat mengerjakan tugas hal ini berdasarkan hasil wawancara dengan AN selaku wali kelas VI A mengatakan bahwa:

"Tentu ada, ada beberapa siswa yang terkadang terlambat dalam mengerjakan tugas dan mengumpulkan tugas. Hal itu terjadi karena kurang dampingan orang tua saat anak-anaknya melakukan pembelajaran daring. Maka dari itu harus ada kerja sama antara guru dan orang tua untuk tercapainya suatu tujuan". (wawancara tanggal 10 Agustus 2021).

Hal ini sejalan dengan yang dikatakan oleh ke 16 siswa. Mereka mengatakan bahwa pada saat belajar tidak didampingi oleh orang tua karena orang tua sedang bekerja dan melakukan aktifitas di rumah. Dan ke 20 siswa kompak mengatakan jika pembelajaran daring di damping orang tua mereka akan sangat faham dalam melakukan pembelajaran daring. Sedangkanke 4 siswa mengatakan bahwa didampingi orang tua. 
Berdasarkan hasil wawancara yang telah dilakukan, maka dapat diketahui bahwa peran orang tua sangat penting dalam hal mengawasi anak belajar. Namun yang terjadi para siswa saat melakukan pembelajaran daring tidak didampingi oleh orang tua. Banyak orang tua yang pergi bekerja dan mengurus rumah sehingga tidak sempat mendapingi anak-anaknya saat melakukan pembelajaran daring.

\section{Implementasi Pembelajaran Daring}

Implementasi pembelajaran adalah pelaksanaan atau penerapan pembelajaran yang memanfaatkan internet sebagai alat bantu serta menggunakan aplikasi-aplikasi yang memudahkan guru dalam menyampaikan informasi. Para guru menggunaka berbagai mamcam jenis aplikasi-aplikasi untuk menunjang proses pembelajaran daring. Dalam melakukan pelaksanaan pembelajaran daring di SD Inpres 68 Kota Sorong di kelas VI A, guru menggunakan aplikasi whatssap sebagai media untuk berkomunikasi dengan siswa hal ini berdasarkan hasil wawancara dengan Ibu AN selaku wali kelas VI A mengatakan bahwa:

"Dengan menggunakan aplikasi via whatsapp dengan menggunakan fitur whatsappgroup kelas. Guru merasa dengan menggunakan whatsapp proses pembelajaran dapat berjalan dengan efektif dan sebagai media komunikasi antar siswa dan guru. Dalam proses pembelajaran setiap pagi siswa melakukan presensi online mulai dari jam 07.30-09.00. sementara siswa melakukan presensi saya mengirim materi pembelajaran dan video-video yang terkait pada proses pembelajaran di hari itu. Untuk pengumpulan tugas yang dikumpulkan melalui cara online, siswa pun mengumpulkan di whatsappgroup dan tugas tertulis dikumpulkan di rumah saya sesuai dengan waktu yang telah di sepakati dengan siswa". (wawancara tanggal 10 Agustus
2021).

Hal ini diperkuat dengan hasil rekapan dokumentasi yang didapat dari guru. Guru memanfaatkan teknologi yang ada dalam membuat video pembelakaran. Guru memberikan video terkait materi pembelajaran melalui WhattsAppgroup yang memudahkan siswa dalam melakukan pembelajaran daring. Siswa dapat mengakses video tersebut melalui HP yang dapat dilakukan dimanapun dan kapanpun. Rencana pelaksanaan pembelajaran (RPP) yang digunakan yaitu rencana pelaksanaan pembelajaran daring satu lembar sesuai dengan anjuran pemerintah.

Dari hasil paparan diatas mengenai implmentasi pembelajaran, dapat disimpulkan bahwa guru hanya menggunakan aplikasi whatsapp untuk berkomunikasi dengan siswa. Dalam penerapannya pembelajaran guru memberikan materi dengan mengguanakan video pembelajaran dan menggunakan buku ajar sebagai bahan ajar yang bersifat mandiri untuk siswa.

\section{KESIMPULAN}

Hasil analisis data mengenai faktor penghambat implementasi pembelajaran daring pada siswa kelas VI A dapat disimpulkan bahwa ada 5 faktor penghambat dalam pembelajaran daring di kelas VI A yaitu tidak bisa akses aplikasi belajar online, keterbatasan ekonomi dan siswa tidak punya HP, jaringan internet, biaya dan kurang dampingan orang tua. Implementasi pembelajaran daring dilakukan dengan cara menggunakan aplkasi whatsapp untuk berkomunikasi dengan siswa yang sangat banyak dengan menggunakan fitur whatsapp kelas.

\section{DAFTAR RUJUKAN}

Ahmad, Susanto. (2015). Teori Belajar Dan 
Pembelajaran Disekolah Dasar. Jakarta: Prenada Media.

Arikunto, Suharsimi. (2010). Prosedur Penelitian Suatu pendekatan Praktek. Jakarta: Rineka Cipta.

Creswell, John W. (2010). Research Design: Pendekatan Kualitatif, Kuantitatif, Dan Mixed. Yogyakarta: Pustaka Pelajar.

A.S. Syarifudin. (2020). Impelementasi Pembelajaran Daring Untuk Meningkatkan Mutu Pendidikan Sebagai Dampak Diterapkannya Social Distancing. Jurnal Pendidikan Bahasa dan Sastra Indonesia.

Bilfaqih, Q. (2015). Esensi Penyusunan Materi Pembelajaran Daring. (Yogyakarta: Deepublish)

Cintiasih. (2020). Implementasi Model Pembelajaran Daring Pada Masa Pandemi Covid-19 Di Kelas III Sd Ptq Annida Kota Salatiga.

Girsang. (2020). Kendala utama yang dihadapi siswa selama belajar daring dimasa pandemic. https://www.edoo.id/2020/08/29/5.

Haerudin, dkk. (2020). Peran Orangtua dalam Membimbing Anak Selama Pembelajaran di Rumah Sebagai Upaya Memutus Virus Covid-19.
Majid, Abdul. (2011). Perencanaan Pembelajaran. (Bandung: Remaja Rosadakarya)

Mulyadi, Deddy. (2015). Studi Kebijakan Publik dan Pelayanan Publik: Konsep dan Aplikasi Proses Kebijakan Publik dan Pelayanan Publik. (Bandung: Alfabeta CV)

Munir.(2009). Pembelajaran Jarak Jauh Berbasis Teknologi Informasi dan Komunikasi. (Bandung: Alfabeta).

Peraturan Menteri Pendidikan dan Kebudayaan (PERMENDIKBUD) nomor 109 (2013) Ciri-Ciri dari Pembelajaran Daring.

Rahmawati. (2020). Analisis Pembelajaran Daring Terhadap Evaluasi Belajar Siswa Pada Siswa Kelas IV MI Ma'arif Kutowinangun Kecamatan Tingkir Kota Salatiga.

Sugiyono (2011), Metode Penelitian Kualitatif Kuantitatif dan $R \& D$, (Bandung: Alfabeta)

Surat Edaran Nomor 3 Tahun 2020 pada Satuan Pendidikan dan Nomor 36962/MPK.A/HK/2020 tentang Pelaksanaan Pendidikan dalam Masa Darurat Coronavirus Disease (COVID19) 